University of Nebraska - Lincoln

DigitalCommons@University of Nebraska - Lincoln

Faculty Publications: Department of Teaching, Department of Teaching, Learning and Teacher Learning and Teacher Education

Education

3-2012

\title{
ICE Raids, Children, Media and Making Sense of Latino Newcomers in Flyover Country.
}

\author{
Edmund T. Hamann \\ University of Nebraska-Lincoln, ehamann2@unl.edu \\ Jenelle Reeves \\ University of Nebraska-Lincoln, jreeves2@unl.edu
}

Follow this and additional works at: https://digitalcommons.unl.edu/teachlearnfacpub

Part of the Social and Cultural Anthropology Commons, and the Social and Philosophical Foundations of Education Commons

Hamann, Edmund T. and Reeves, Jenelle, "ICE Raids, Children, Media and Making Sense of Latino Newcomers in Flyover Country." (2012). Faculty Publications: Department of Teaching, Learning and Teacher Education. 127.

https://digitalcommons.unl.edu/teachlearnfacpub/127

This Article is brought to you for free and open access by the Department of Teaching, Learning and Teacher Education at DigitalCommons@University of Nebraska - Lincoln. It has been accepted for inclusion in Faculty Publications: Department of Teaching, Learning and Teacher Education by an authorized administrator of DigitalCommons@University of Nebraska - Lincoln. 


\title{
ICE Raids, Children, Media, and Making Sense of Latino Newcomers in Flyover Country
}

\author{
Edmund T. Hamann and Jenelle Reeves \\ University of Nebraska-Lincoln
}

\begin{abstract}
Extant cultural models articulated in "Flyover Country" print media responses to ICE workplace raids showed a welcome of sorts of Latino newcomers. These models suggest a place for Latino students at school and more broadly for Latino children and parents in these communities. Thus, they index an unwillingness to see Latino newcomers in dehumanizing reductive terms, like "alien" or "illegal," even as these more debilitating models may also be extant elsewhere in the public sphere.
\end{abstract}

Keywords: cultural models, new Latino diaspora, media, flyover country, public sphere

Speaking recently to the National Council of La Raza, Barack Obama told the audience what it wanted to hear when he said, “The system isn't working ... when communities are terrorized by ICE immigration raids - when nursing mothers are torn from their babies, when children come home from school to find their parents missing, when people are detained without access to legal council."

- Ruben Navarette, 2008, p. 5B

\section{Introduction: Culture Models from the ICE Raids of 2006 and 2008}

Then-candidate Obama's July 2008 comments to the National Council of La Raza's (NCLR) annual conference referenced community traumas related to recent Immigration and Customs Enforcement (ICE) raids mainly in the "Flyover Country" region (i.e., the Midwest, Great Plains, and Mountain West - the space that metropolitan Americans "fly over" as they travel between the coasts). In his address to NCLR, Obama faced a dilemma familiar to political candidates: how to be appealing to the audience in front of him - that is, Latino activists - without being alienating to the larger electorate who were likeliest to see just snippets of his comments run and rerun on the nightly news or published in news and editorial pieces (which is how we encountered them).

Yet this dilemma was not as fraught or complex as it first appeared. In his sympathetic remarks to NCLR activists, Obama was also using language that echoed that found in regional texts generated by mainstream Flyover Country print media (e.g., the Des Moines Register and Greeley Tribune). These sources had offered earlier and more quotidian references to the raids that gave Obama themes to draw on. It is these latter texts that serve as the main focus of this article. They tell us about Flyover Country's contemporary negotiation of a new Latino presence and they point to a solution, however wavering and incipient, to a problem outlined well by Enrique G. Murillo Jr. in his concluding chapter to Education in the New Latino Diaspora. Murillo worried about "the limited accepted identities of Latinos" and "dehumanizing [of Latino newcomers]" in both workplace and school settings (2002:230) in the new Latino diaspora (i.e., the parts of the country where a substantial Latino presence was only a relatively recent demographic fact). He argued that subordination of Latinos depended on reducing human beings with multiple, varied, and broad identities into narrower and dehumanized categories like "laborer" or "alien." Yet 
neither Obama's comments nor the newspaper depictions shared later engage in this dehumanizing. Indeed, they offer public sphere assertions of Latino newcomers' humanness, their roles as parents, neighbors, students, kids, strivers, etc.

In referencing the raids, Mr. Obama invoked cultural models (Quinn and Holland 1987) - that is, socially created ideas that are broadly extant in society that guide and shape both how we think and act-to appeal to an audience that was frustrated and angered by the dramatic recent increase in workplace raids and by the community upheaval those raids had caused. As Obama knew, invoking parents' separation from children, children's terror, and children leaving school uncertain of whether adults in their life would be home to greet them are each powerfully emotive story lines and lead most listeners to feel sympathy for the disrupted, to feel solidarity with Obama in his criticism. Candidate Obama could have referenced other storylines and details related to the raids. It is telling that he did not.

Yet our interest is not in national politics or presidential calculations per se. Instead, our goal is to look at how community, migration, newcomers, workplace, school, Latinos, and children were all being understood regionally in mainstream print media during the second half of the first decade of the 21st century by considering the cultural models used by small and large local print media sources in their depictions of the ICE raids and their aftermaths. In particular we are interested in seven nationally prominent raids. Six were the concurrent ICE raids that involved six Swift meatpacking plants just before Christmas in 2006 and the seventh was the May 2008 ICE raid at a kosher meat-processor in Postville, Iowa.

\section{Print Media as a Source of Mainstream Discourses and Cultural Models}

Print media are not the traditional data source for the anthropology of education, but we turn to them, nonetheless, for a number of reasons. First, although we think our focus on how children, schools, and teachers (among others) are understood suffices to put this inquiry within the traditional boundaries of our subdiscipline, we also note that print media have a popular educational role; they provide the content that the reading public consumes. We agree that, just as in schools where what is taught is not necessarily what is learned (Erickson 1987), what is printed in the media is not necessarily what readers ultimately internalize or concur with. Nonetheless, print media depictions become a starting point for what is imaginable, a point we will return to in the subsequent discussion of cultural models.

Second, print media are an obvious venue for a consideration of the public sphere, whether one views the public sphere through either of two lenses. The public sphere can be understood per its original liberating potential as described in a traditional Marxist view (which highlights the public sphere as a space for consideration of social conditions, policy, and political authority that is itself separate from state authority) or through Habermas's critique of this traditional notion (Hanks 2011). Habermas complained that the bourgeois merchants, property owners, and other locals of substance (whose historic access to literacy, leisure, and urban settlements meant they were the first to constitute and dominate public spheres) did not actually tolerate populist voices, particularly if they were in opposition to bourgeois interests. As readers will see, we find both of these understandings of the public sphere to be useful. We found print media (incl. web sites of daily newspapers) to be spaces where social conditions were considered by editorialists, reporters, and their informants who were not formally affiliated with the state. Yet we would concur, per Habermas, that in this public space not all prospective public voices were equally welcome, with certain opinions relegated to "reader comments" or "lettersto-the-editor" (or perhaps excluded altogether) instead of given the imprimatur of a reported story or editorial. 
As a third rationale, print media offer an intriguing alternative to the ethnographer's usual advantage of "being there." While looking at local print media retains some of the geographic situatedness that characterize anthropology's traditional domains of, say, an island, a village, or a school - the Herald Journal of Logan, Utah, does claim a geographic focus around Logan, Utah - it has the added characteristic of showing how nonlocal ideas (e.g., an Associated Press story) are part of what circulates locally.

Because our goal was to consider dominant local discourses, reviewing print media (and some published reactions to those media) provided a useful filter for our data collection. We examined what "made it to print." Consideration of that coverage allows us to weigh the ideas, storylines, and cultural models that were invoked (wittingly or not) by the reporters and editors who prepared the examined copy. Examining the copy also offers some measure of what readers would find interesting, salient, or evocative. Reviewed sources include:

Associated Press [carried in local newspapers]
Dallas Morning News
Des Moines Register
Grand Island Independent [NE]
Greeley Tribune [CO]
Times-Republican [Marshalltown, IA]
Lincoln Journal-Star [NE]
Herald Journal [Logan, UT]
New York Times
Salt Lake Tribune
Pioneer Press [St. Paul, MN]
Worthington Daily Globe [MN]

Because of their proximity to the sites of the raids, most of these media sources were monitored daily from date of the first raids, December 12, 2006, through December 31 of that year and, using a cut-and-paste function, an archive of local coverage was created. Later, we monitored the May 2008 raid in Postville, Iowa, through the Des Moines Register and the New York Times. That monitoring was more intermittent, but because both newspapers included "related links" we are confident that our monitoring captured most of both papers' coverage of the seventh raid and its aftermath.

While the New York Times in many ways is not a daily local newspaper of record for Flyover Country, because the raided Postville, Iowa, kosher meat-processing company was owned by New Yorkers, in that newspaper, too, there was a local interest tie-in. Moreover, our inclusion of the New York Times allows us to illustrate that a national media outlet known and critiqued (in certain circles) for its "liberal" tendencies offered coverage that was not substantially out of synch with the other more local or regional voices.

For only some of the articles did the newspaper websites allow reader comments and, when they did, only sometimes did we monitor such commentary. However, we read enough of the commentaries to note that they were often outlets for a few heated and shrill local voices that were very much in dissent with the tone of coverage of the local newspaper. We say "few" because (like the example of Jennifer O. shared shortly) the same individuals often posted multiple times. We say "in dissent" not just because these views found little echo in the regular coverage from local journalists, but also because of our familiarity with dissenting letters-to-the-editor in other U.S. settings that have negotiated relatively new Latino in-migrations (Hamann 2003a, 2011).

As more recent anthropology of education publications have reminded us (Hamann 2003b; Hamann et al. 2007), more than 40 years ago Laura Nader (1969) urged our whole discipline to "study up." She also warned us not to lock ourselves into adherence to a par- 
ticular methodology (a stance echoed by Wolcott [1988]) but, rather, to let our research questions guide how we pursued our research. This article seeks to, in Wolcott's words, "look at things not ordinarily looked at, from perspectives not ordinarily taken" (1988:15). While a traditional ethnography could intriguingly illuminate how heterogeneous members of at least one of the raided communities reacted, the intent here is to identify what might pass as mainstream, local, public-sphere shaping "elites" as they drafted one of the most obvious and accessible records of what the raids locally meant.

Agreeing with Rockwell (2011:66) that discourse analysis has much to offer the anthropology of education and echoing Santa Ana (2002) and his critical discourse analysis (which draws from Fairclough in particular and to a lesser extent Foucault, Goffman, and Lakoff), it is our contention that mainstream regional media largely reflect dominant public attitudes even as they help shape them. As Santa Ana notes (2002:18-19), Fairclough argues that mainstream media, as dominant voices in public discourse, can shape the particular definitions of words, act as stage directions for social interaction, bound that same stage, and reaffirm the discourse provider's identity. Making this less abstract, newspaper stories in Flyover Country played framing roles in determining what words were used to talk about the ICE raids and those affected, provided a venue for public meaning-making related to those raids, delineated which interpretations were mainstream and which were not seen in such a light, and reiterated their own authority as mainstream "sensible" news sources.

Thinking about the media coverage of the six concurrent raids at Swift meatpacking plants in December 2006 and a seventh raid in Postville, Iowa, in May 2008, we can find angry dissenting voices to the moderate newspaper accounts that we share later. For example, nine days after a local raid, reader Jennifer O. wrote to the Worthington (MN) Daily Globe:

To those of you good people who are taking up collections and paying bills for those people affected by illegal immigration - Would you do the same for American citizens who lose their jobs because they broke the law? Would you open your hearts and your wallets to pay their bills? Come to think of it, these illegal immigrants have a good thing going. They work under false credentials, get the same benefits as legal Swift employees, have time off from working to take care of their legal troubles and get all their bills paid while they do it. Many of them will continue to welcome what you offer them until they get back to work. What a good deal. If you actually saw the reality of it all, you would feel like a fool who was used. [Worthington Daily Globe 2006]

But, as perhaps this letter writer's shrillness suggests, voices like hers were not characteristic of the mainstream coverage, hence her compulsion to try to be heard online. Indeed, she had posted to the same reader commentary blog three days earlier (and six days after the local raid):

Why do you continue to use children to garner sympathy for people who take advantage of what this country has to offer when most of them have no intention or desire to become loyal citizens of this great country? The media is just as guilty, if not more so, for spreading and enflaming outright lies to a compassionate and gullible public. If it weren't for your duplicity, these immigrants would never have arrogantly believed that they were welcomed with open arms in spite of their illegal status. Their comfort in breaking the law came in large part from the liberal media. Where do you think they learned how effective it is to use the plight of children to get what they want? You should be ashamed.

Like candidate Obama, Jennifer $O$. felt compelled to reference the mainstream media's emphasis on children in its accounts of the raids, even if her goal was to try to challenge those representations. Local media had set the stage regarding what mattered and what was under discussion; Jennifer $\mathrm{O}$ (and others like her) could only react. 
As Quinn and Holland write:

Undeniably, a great deal of order exists in the natural world we experience. However, much of the order we perceive in the world is there only because we put it there. That we impose such order is even more apparent when we consider the social world, in which institutions such as marriage, deeds such as lying, and customs such as dating happen at all because the members of a society presume them to be. [1987:3]

As other examples of socially imposing an ordering to the world, members of a society presume that children should not be separated from parents, that those from other lands who accept U.S. jobs should be called "illegal" (or not), and so on. Quinn and Holland go on to describe cultural models as the currency or connective tissue of this culturally inflected social world. Terms like "newcomer" and "illegal alien" can both be invoked to describe the same person, but the choice of one versus the other is powerfully consequential for how we understand the invocation and the way we subsequently view and act toward the referent (Lakoff and Ferguson 2006).

Noting the turns of phrase in Obama's speech quoted in the epigram, he used terms like "nursing mother," "children," "school," and "parent," but (at least here) refrained from the phrase "illegal." Obama's word choices were no doubt purposeful, positioning him to be seen as an advocate of nursing mothers, children, schools, and parents, and inviting his audience to join him in concurring with this framing of the Flyover Country raid victims he was alluding to. As U.S. Senator John D. Rockefeller has noted (see Rosen 2009:269), "There are very few symbols as powerful as kids."

In invoking children (and the other terms), it is unlikely that Obama thought he was introducing something new to his immediate audience. Rather he was invoking themes and knowledge that his audiences, at the speech and those accessed through media coverage, brought with them. In saying "nursing mothers," his goal would have been to evoke love, care, affection, nurturance, etc. Presumably the idea of separating a nursing mother and baby would both resonate and be understood as wrong. After inviting these connections to his words and his audience's memory and senses of selfhood, it would then be Obama's calculation that an allusion to how such people were wronged through the course of ICE enforcement should generate agreement about both his interpretation and his invitation for them to join him in producing and supporting different outcomes.

Thus, cultural models are bigger than just particular turns-of-phrase because they invoke a much larger body of experience, history, and senses of identity or position. They link the invoker and the invoked through the shared solidarity of agreeing on socially created facts (Quinn and Holland 1987). Cultural models build from collective and historical thinking (e.g., schools should be safe, nourishing places) and overlap (e.g., students be protected and assisted). But contradictory models can coexist and compete with each other (e.g., newcomers are illegal aliens vs. newcomers are familial, thrifty, hard workers [Suárez-Orozco 1998]). So it becomes important to consider who evokes which models, as that explains how some models become mainstream while others are considered marginal.

Acknowledging that humans are not perfectly rational creatures, we do make sense of the world and derive from that sense-making both an understanding of what the nature of the world is and how we should act (Wolcott 2011). Informing this sense-making is our sense of self or identity. Both sense of self and sense-making are socially mediated through our invocation and consumption of cultural models. Human interaction is replete with intertwined ideas and actions that embed varying versions of what is and what should be. In a sense then cultural models are the building blocks of community and social being. While their full salience is sometimes partially obscured and their intended meaning can differ from how they are understood, cultural models are often visible in language, so written text that functions as a kind of in situ community record is a partic- 
ularly appropriate site (1) to identify cultural models and (2) to characterize through considering those models how demographic transition and community identity, including inclusion, were negotiated.

\section{Cultural Models and the December 2006 ICE Raids}

On December 12, 2006, concurrent ICE raids were conducted in six Swift meatpacking plants across the Great Plains and into the Rocky Mountain region including Worthington, Minnesota; Marshalltown, Iowa; Grand Island, Nebraska; Greeley, Colorado; Hyrum, Utah; and Cactus, Texas. The raids took place during the day, mostly in the morning hours, while the school-age children of many detained in the raids were attending their elementary and secondary schools, on an otherwise typical Tuesday. Media reports of the events quickly focused not only on the alleged crimes of the detainees (e.g., identity theft) but also on the chaos and upheaval experienced by detainees' children, their schools, and others collaterally impacted by the raids in each of the six communities. Practically all of the detainees and affected children were Latinos.

Broadly, newspaper accounts referenced two cultural models in telling the ICE raid stories: first, a narrative of children as innocent victims applied to detainees' children, with an accompanying storyline of schools as sites of refuge and teachers and administrators as step-in family for children, and, second, a narrative of raids as a violent act visited on communities in which the fabric of community life was rent with even documented residents erroneously detained and all community children terrorized. Not only were each of these cultural models evident in the newspaper accounts from each site, but also the models informed and supported each other.

The cultural model of children as innocents permeated the media coverage. In some cases, school-age children of detainees returned home to empty houses or homes with one less parent or guardian. In the cases where schools were notified in advance or in concurrence of the raids, other detainees' children were kept at school until friends or relatives could be identified. (Per a 1982 U.S. Supreme Court case, Plyler v. Doe[457 U.S. 202], schools are prohibited from asking about children's or parents' documentation status; however, because of this ruling, schools in the raided communities generally lacked information regarding what parents or guardians would be available in the case of an ICE raid.) In either case, the tragedy of children separated from parents and guardians became a primary and persistent storyline. A December 14, 2006, article in the Worthington Daily Globe (MN) read:

Jesus Alcantar, a Swift employee and union representative, said through an interpreter that he had found four children knocking on doors looking for their mother. "I took them by the hand and started knocking on doors, looking for family members who would take them in," he said. "I saw a little girl on the street. I saw someone take her, but I don't know who that was." Alcantar said if anyone knows of children still misplaced to take them to churches, so they can be placed or "paired up" with their families. There were no concrete numbers about how many children were displaced, but De Leon said one child is too many. [Wettschreck 2006]

Although, by one way of reading, this is just a factual account of what came to pass, a "search" for cultural models in even this snippet of the larger article is revealing. For one, even ignoring the happenstance of the first quoted source having the name Jesús (produced in the article without an accent), it is intriguing to see that the first source is identified by his full name, a reminder of his personhood, that, in turn, inflects how the next passages are to be read. These next turns of phrase include "I took them by the hand," "looking for fam- 
ily," and "little girl on the street," with each raising the specter of vulnerability and innocence. The article then notes the role of churches as institutional settings for family reunification. The framing here is decidedly not one of rule breaking, violations, and punishment (although that would be an alternative way of conveying the same story).

In Hyrum, Utah, the [Logan] Herald Journal reported community members' worries over children's emotional welfare. "Another parent, Judith Quan, said her main concern was for the children: 'These poor children. I can't imagine what they're going through. People are very afraid"' (Geraci 2006). This storyline was echoed in Grand Island, Nebraska. "'I know this is the law, but it is very hard when they take the fathers and leave the kids alone at home,' Alvaro Paiz of Grand Island, president of the Hispanic Chamber of Commerce said. 'I think they can find better ways to make this process happen'” (Pore 2006).

The Dallas Morning News reported more than 400 children were left parentless in the Cactus, Texas raid, noting that the situation was made all the more poignant by the approaching holiday season. In an article a few days after the first flurry of raid coverage, the Greeley Tribune[CO] reported the story of detainees' children facing the holidays without one or both parents.

Holding a small rectangular box wrapped in white Christmas paper, 6-year-old Esperanza Zarate of Greeley stood debating what it could be. "I was a good girl this year," she said, smiling. "I asked Santa Claus for a pony for Christmas. A big one."

She was among nearly 1,500 families who attended the ninth annual Migrant Christmas Fiesta at Northridge High School on Saturday. Her father, Candido Zarate was taken in the raid Dec. 12 at Swift \& Co. meat packing plant in Greeley. Her mother, Sara Zarate, said she's been trying to keep her five children busy but still they are beginning to ask where their dad is. "I know my 8 year-old is trying to be strong," Zarate said. "I don't think it's hit them yet. They just keep seeing me cry."[Delgado 2006]

In this instance, the invoked cultural model of children as innocent victims of this larger enforcement action was amplified by references to Santa Claus (positioning readers to think of their own childhood Christmas experiences or their experiences perpetuating the Santa Claus story to their children or others). Readers here were also asked to consider a mother's struggle (in the face of the ambiguity of what happens after her husband's detention) to share or not share painful news with her children. Although in each of these stories, Latino identities of children and detainees were identifiable, the thrusts of the story do not emphasize this as a salient point of difference; rather the emphasis seems to be on things these children and their families have in common with what is likely a mostly white and mostly middle-class readership (e.g., church, Santa Claus, children worrying about their father's whereabouts).

Children attending classes that December 12 were unaware of the detention of their parents and, in some instances, it appears schools were also unaware (as the earlier example from Worthington, Minnesota, illustrated). Also common, however, was schools' improvised and extended role of providing safe harbor to children as efforts were made to identify with whom children could go home. Newspaper accounts highlighted the role of schools as sites of refuge and educators as stand-in parents. The Herald Journal in Logan, Utah (near Hyrum), reported:

In the midst of legal jargon and arrest statistics, the children of adults detained in Tuesday's E. A. Miller raid are the innocent victims, and the puzzle piece that makes this situation human, local educators are saying.

School officials have been working overtime in the aftermath of the multi-state police action to comfort students affected both indirectly and directly by the raid at E. A. Miller, officially known as Swift. [Wheeler 2006] 
The newspaper account humanizes the raids through the plight of affected "children" and "students" who are to be comforted. In this way the human tragedy of the raids and the compassionate but onerous extra work of schools and community dominates the visible discourse of the mainstream media, rather than other possible themes such as the lack of documentation of workers or the detainees' misuse of identity papers.

Some schools at the raid sites, like those in the Cache County School District that includes the town of Hyrum, Utah, received same-day notification of the raids and scrambled to make plans to hold detainees' children after school hours, a plan that was complicated by the fact that schools were not told whose parents or guardians were actually detained. Schools became de facto sites of refuge, and media noted the stand-in parental role teachers and administrators played in protecting and calming affected children.

Just a few miles up the road from E. A. Miller, Mountain Crest High School administrators spent part of their day addressing the concerns of the roughly 100 Hispanic students who attend. And at South Cache 8-9 Center, about 30 students with Spanish surnames were called to the front office over the public address system.

Mountain Crest Assistant Principal Sheri Hansen said officials are steeling themselves for the possibility of having students with one or both parents in federal custody.

"We have ownership of these kids, and we love them," Hansen said. "The fact that they're devastated kills me. I hate it."

She said the school's guidance counselors and ESL teachers were made available to students who might have questions about the incident, and Murillo met with some of them at a gathering on Tuesday.

"A lot of the kids were really worried sick and crying," he said. "One of the problems is they see this raid as a nightmare they always knew about, and now it's coming down on their parents and aunts and uncles."

Milt Liechty, deputy superintendent of the Cache County School District, said the schools will continue to be a safe haven for all students enrolled in them.

"The bottom line is we're going to absolutely help these kids as much as we can," Hansen said. [Benson 2006]

This story invokes the cultural model of educators as caring, stand-in parents to students and uses that claim (articulated by Asst. Principal Hansen) to emphasize the tragedy of the raids. In a sense, the article acknowledges to its anticipated readers that "you may not know these kids, but you know me (or people in my role) and because I know and love these kids and feel their devastation, so should you."

Similar reports were given of schools and school officials in Cactus, Texas, and Worthington, Minnesota.

Some of the most dramatic scenes during Tuesday's raid occurred at Cactus Elementary School. Officials kept students inside until parents, relatives, or close adult friends came to pick them up.

Superintendent Larry Appel said he expected all the students to be retrieved by relatives by nightfall. [Trejo and Morales 2006]

"I've never seen anything like it, the sadness, the emptiness, the fear," a schoolteacher [from Worthington, MN], Barbara Kremer, said. Ms. Kremer said she had provided shelter in her house since the raid for 24 immigrants who were afraid to return to their homes. [Preston 2006]

In both of these examples we see invocations of schools as a site of safety and shelter, with that understanding, in Ms. Kramer's case, casting her as a source of shelter even away from the school setting. Within this kind of framing, it is not unexpected that a superintendent was quoted assuring community members that students were being looked after, nor that a 
teacher took personal action to care for students. These invocations help advance the larger point. While the idea of schools as safe places is not new (rare dramatic examples of high school shootings being an exception to this understanding and horrifying in part because they violate expectations), this extension of school to be a safe site in the face of a raid could concurrently fit readers' expectations (i.e., of schools as safe places), but also support outrage against the raids (i.e., schools should not be asked to carry this burden, too).

If we accept the idea that print media coverage of ICE raids were reflective of particular regional understandings (i.e., mainstream cultural models of what should and should not occur or be tolerated vis-à-vis the presence of newcomers), then this invocation in the media of storylines of innocents being hurt and of valued institutions (schools) being asked to carry an unreasonable burden, become larger challenges to both the particular strategy of workplace raids and to the larger logic that permits or encourages them. In this sense, these mainstream local accounts challenged the righteousness and appropriateness of the ICE actions and suggested a welcome or place of sorts for Latino newcomers: Children in our community should not be separated from their parents. These kids are loved by their teachers. The action of an external they (ICE) should not interrupt a stable we-that is, a community that includes Latinos as part of its whole.

Sympathy for detainees' children and admiration for schools that stepped in as sites of refuge accompanied anger at immigration officials who planned and executed the raids with little thought of consequences to children and community. Two days after the raids, the Worthington Daily Globe included this reportage:

\footnotetext{
"I'm ashamed to live in a country where this kind of thing happens," Ricker said, "where laws are enforced with a club instead of with intelligence and forethought."

Ricker added that he couldn't believe ICE, with all its years of experience, couldn't take more steps to ensure children were not sent to empty homes. De Leon also commented about ICE not taking steps to make the schools aware of what was happening. [Wettschreck 2006]
}

Further anger was directed at ICE for detaining even those legal residents who simply did not have their identification cards with them at the time of the raid. In what was likely a case of racial profiling, all suspected of being undocumented were detained and transferred to detention facilities sometimes out of state. Some 75 legal residents detained in the Greeley $(\mathrm{CO})$ raid were taken into federal custody and transferred to Texas before their status could be verified (Greeley Tribune Staff Reports 2006). Dan Hoppes, president of the United Food and Commercial Workers Union Local 22 in Grand Island, Nebraska, was among those pointing up ICE ineptitude.

It's my opinion, and the opinion of the international union, if there's criminal action, we don't condone criminals or any kind of illegal activity, but, by the same token, they could have come into these plants with warrants and arrested these people who are in violation without completely disrupting the whole community and the Hispanic population and whoever may be an immigrant. [Overstreet 2006]

Here again we see accounts that challenge the justification of the government action and draw we-they lines, which include at least some Latino newcomers among the we (differentiating immigrants from criminals).

The raid (and the raiding strategy) was less okay if cherished understandings, like the importance of community, were interrupted in its implementation. These challenges could not undo history, but they appeared to have affected ICE strategy for the Postville raid in 2008, and they have a second relevance in the ways they reiterated or amplified existing latent understandings related to community and place: Greeley should not be a place where the innocent are detained. Nor should Grand Island be a place where the whole community could be profoundly disrupted. 
Dallas Morning-News coverage of the raid that included Latinos when it referenced "residents of Cactus" offered a personalized account of one determined patriarch who stepped in to care for children of detained family members:

Mr. Escarcega said his family would continue as best they could, even though residents feared that immigration agents would soon be going door-to-door. As dusk fell and temperatures dropped into the 30s, other residents of Cactus waited anxiously behind closed doors or visited homes of relatives and friends. They struggled to make sense of what had happened. [Trejo and Morales 2006]

In response to the similar dilemma in their town, the editorial board of the Greeley Tribune invoked respected community institutional entities (at least respected in this context), like businesses, churches, and schools and was intentionally ecumenical in its inclusive reference of coming rituals as it rearticulated a vision of community that the raid had disrupted.

We call on residents, city officials, businesses, churches, organizations, schools and community leaders to help keep the raid at Swift from further dividing us. Instead, let's use this as an opportunity to join together. What better way to experience such bonding than through helping others - especially during this intense holiday season: The Jewish holiday Hanukkah began Friday night, Christmas is in eight days and Kwanzaa begins in nine days. Greeley has a giving, loving soul. [Greeley Tribune 2006]

The culture models invoked in the coverage of the 2006 raids challenged those same raids. Local coverage in the Marshalltown Times-Republican of a letter sent by U.S. Senator Tom Harking to Secretary of Homeland Security, Michael Chertoff (Homeland Security has jurisdiction over ICE) and a proposal by the Times-Republican publisher that Marshalltown host a conference on immigration reform highlighted a proposed twinning of a local and national response:

Sen. Tom Harkin, D-Iowa, Tuesday called for a complete overhaul of the nation's immigration system, while the Times-Republican is calling for a federal summit on the issue to be held in Marshalltown. In the wake of the recent Immigration and Customs Enforcement (ICE) raids on Swift \& Co., Harkin sent a letter to Homeland Security Secretary Michael Chertoff to express concern about alleged humanitarian and civil rights abuses against detainees, and to urge the agency's cooperation with Congress in implementing comprehensive immigration reform. . . In the letter, Harkin points to reports that the hotline by which family members and others were supposed to obtain information about detainees and their status had gone unanswered at times by ICE officials, and at other times provided no information of any use. He singled out the difficulty detainees had in accessing legal or religious counsel.

Harkin also expressed his dissatisfaction that, despite assurances provided to his staff that any individuals with small children who would otherwise go without care would be released to make alternative arrangements, there were repeated reports of numerous single mothers remaining in custody. ... Marshalltown was one of six sites around the country to get raided by federal officials last week, but was the only one in the state of Iowa. A federal summit on the issue would be especially valuable if it were held in Marshalltown because of the city's experiences with immigrant populations. "Having key decision makers here and having them listen to what the Hispanic community, city/county government, the schools, the hospital, the business community, the chamber, MEDIC and other agencies have to say about immigration should prove to be valuable for those making policy," said Times-Republican Publisher Mike Schlesinger. [Black 2006]

Throughout the reporting on the December 2006 ICE raids, most accounts of employees detained mentioned little more than their alleged crimes, although a few accounts gave voice to family and relatives who portrayed the detained employees as "a good dad" (Benson 2006) and people "just here to work" (Trejo and Morales 2006). In other words, 
the culture models that protested the consequences of the raids, did not much directly challenge the framing of most of the detained as illegal or criminal, but instead offered other identifiers for how they and, crucially, their children were understood. Moreover, very little attention was given to Swift, which employed all of those detained. What was and was not controversial in coverage of these first raids appeared to matter for how ICE planned and implemented the later, May 2008, raid in Postville, Iowa.

\section{Shifts in Detention Tactics and Cultural Models: Postville, 2008}

Perhaps in response to the negative public portrayals the agency received in 2006, ICE changed its capture and detention tactics when it raided the Agriprocessors meatpacking plant in Postville, Iowa, on May 12, 2008. In that raid, ICE made a much more concerted effort to verify whether those being detained had children in school or daycare. And there were no accounts this time of children stranded at school or of teachers becoming providers of shelter. Instead, in the Postville raid, one detained parent (usu. the mother) was banded with an ankle bracelet and released to house arrest to care for her children. This strategy avoided the separation of mothers and children, avoided the hazard of children being stranded at schools with it being unclear if there were adults at home to go home to, and at least superficially appeared to have solved some of the collateral hazards that had lessened local community support (in media portrayals) for the earlier Swift raids.

Nonetheless, perhaps because it was easiest to invoke familiar storylines, the cultural model of detainees' children as innocents and victims still characterized media accounts of the May 2008 Postville raid. This time, however, the model shifted to include mothers as victims, too. In Postville mothers who had been released to a kind of house arrest (monitored by electronic ankle bracelets) were available for reporters to access as they continued coverage of the story. In this new coverage, while the unauthorized nature of the mothers' predetention employment remained a salient fact, the more overwhelming fact in the way they were portrayed in print media accounts was their status as mothers. After all, it was this status that helped explain their continued temporary presence in the community, although they also were kept in the community to be witnesses for prospective prosecution of Agriprocessors management (a detail that had not been part of the earlier Swift raids). Thus, although these mothers may have been "guilty" of working without documentation, their treatment at the hands of ICE was storied sympathetically, even tragically in local print media coverage. The story of Irma Hernándes, as told in the Des Moines Register a few weeks after the raid, provides an example:

When Irma Hernándes lies to her children, she does it modestly. She tells them things will be fine, that school will be easy, that they'll make new friends.

When Hernándes and her children return to Guatemala - and they almost surely will-they will be going back to a country Hernándes left four years ago for a better life in the United States. She came here illegally, as did at least 388 other workers at the Agriprocessors Inc. meatpacking plant. She was caught in the poultry section with her husband in a raid on May 12.

He was detained, processed and sentenced to five months in jail. She was released on humanitarian grounds - she had to care for her children, ages 9 and $11 \ldots$

Now, she wears a tracking bracelet on her ankle, one of 42 women and three men who were released and still await their fate...

She lives in a modern A-frame in Postville that costs $\$ 700$ month. She doesn't have much money. What little she and her husband saved went to immediate costs after the raid. That ran out quickly, and now she's reliant on the local Catholic church to pay for her rent and utilities. [Duara 2008]

In this account, Irma was first described as a modest and protective mother who cared about her children's schooling; then the United States (and by extension Postville) was 
characterized as a place for "a better life"; then the Catholic church was named as assisting her in her moment of need (conveying a Christian service connotation to how she should be understood). None of these portrayals denied her undocumented status but, almost as if in direct response to Murillo's (2002) concerns, they did make her public identity both more nuanced and more sympathetic.

Irma and other mothers like her became known in town and in the media as the mujeres de braceletas, women freed (sort of) to care for their children, but left without an income in the United States and without the clearance at that point to return to Guatemala, the home country of many Postville detainees, to seek employment there, either. As noted in a later Des Moines Register account:

Now, about 20 to 25 women remain tethered to the bracelets, black electronic monitoring devices that dig into the skin of their right ankles, leaving dark bruises and painful cuts. Some women try without success to protect their flesh with makeshift bandages fashioned from bandanas and short socks. [Rhor 2008]

As the cultural model of children as victims enlarged to include their mothers, the portrayal of detained employees grew more sympathetic, as the salience of their "illegal work" faded in relation to their framing as mothers, as adults stuck in a legal limbo, and literally as victims physically pained by their monitoring devices.

In the Postville raid, 389 people were detained. As with the previous raids, community disruption was widely reported, "'A lot of good workers were taken away, a lot of good families are gone,' " said Kim Deering, 48, a lifelong Postville resident “... the community is drained ... we are grieving, sad, apprehensive" (Rhor 2008).

Although Reynolds and Didier (in press) have found through their ethnographic studies that the orientations of non-Latino, long-time Postville residents to Latinos were varied and were far from uniformly accepting, there was a noticeable sympathy in the mainstream media accounts. The culture models invoked were purported to be emblematic of community mores, mores that more ardently portrayed detainees as "good workers," welcome community members, and even victims of an exploitative employer, a storyline that had rarely emerged in the previous Swift coverage. With the Agriprocessors raid, newspaper accounts reported tales of employee abuse.

In one case, a supervisor [had] covered the eyes of an employee with duct tape and struck him with a meat hook ... [a]nother plant worker told federal officials that undocumented workers were paid $\$ 5$ an hour for their first few months before receiving a pay increase to $\$ 6$ per hour. The minimum wage in Iowa is $\$ 7.25$. [Duara et al. 2008]

Agriprocessors, a kosher meatpacker, received much criticism for its management of the plant in Postville, including a scolding from Iowa's governor, who reminded the company in a guest column in the Des Moines Register that they must "operate responsibly" (Culver 2008). The governor, Chet Culver, further noted,

\footnotetext{
The sad events surrounding the federal Postville raid, resulting in multiple federal criminallaw convictions of line workers and low-level supervisors - and, notably not yet of the company's owners-are strong evidence of a company that has chosen to take advantage of a failed federal immigration system. [2008]
}

Perhaps the most illustrative example of the expansive and sympathetic cultural model through which Postville's newcomer families were understood was the Des Moines Register's continued coverage of Postville detainees well after the raid. Even after detainees had returned to Guatemala, the Des Moines Register sent a reporter to cover the return of some to their native land, including Vincent Sanail Lopez who, on return to Guate- 
mala after months of detention and no income, faced losing his family's ancestral land. Of course, to Iowans who remembered the farm crisis of the 80s and 90s, a loss of land would be a particularly potent cultural model to invoke.

Sanail put the property up for collateral for a loan that covered the travel costs for him and his 30-year-old son, Benjamin. They still owe about $\$ 4,000$ on the loan, and if they can't repay it, they could lose the land ...

Before he was arrested, Sanail sent home about three-quarters of his earnings from Postville. The family used the money to buy concrete blocks, mortar, and steel reinforcing rods. Now, the rusting rods stick out from the top of the walls, which are about 5 feet tall. Sanail had planned to move back after the project was done, and live out his days in a decent house. Now, the unfinished project is a constant reminder of dashed hopes. [Leys 2008]

As in the coverage of the Swift raids, mainstream regional print media coverage of the Postville raids invoked human tragedy, vulnerable children, loving parents with educational aspirations for their children, and other sympathetic storylines. Although, as in 2006, angry anti-immigrant voices could be found in online responses to local coverage, those were not the mainstream-approved interpretations as manifest in the newspapers.

\section{Conclusion}

Related to the Swift raids in 2006, we flagged two discourses, threading together cultural models: the first decried the horror visited on Latino children and families related to separating parents and innocent children and bemoaned schools needing to step in as sites of safety and custodianship; the second lamented the cleaving of community cohesion caused by the raids. Both of these discourses asserted the same mainstream understandings as candidate Obama invoked in his speech and both gave little attention to more marginal and angry local voices (like that of Jennifer O. in Worthington) who rejected the mainstream interpretation. Both of the mainstream discourses included a place for Latino newcomers in Flyover Country with children's status as local schoolchildren an important part of that argument for place.

In the first series of raids, when parents were detained, schools faced the challenges of what to do with those parents' children and also how to negotiate many other children's new fear that somebody could come and take their parents while they were at school. Local media voices invoked cultural models to protest at least the collateral damage of the raids and, in so doing, not only may have provoked ICE to change its strategy for the later Postville raid but also offered several important local articulations about what local reality and activity should and should not entail. Media voices projected a familial, coherent, and communitarian, albeit no longer homogeneous, sensibility about what Flyover Country towns and cities were and should be. As importantly, newcomer Latinos were somebody's student, somebody's spouse, and somebody's fellow parishioner.

Since then, for example with the ICE raids in Postville, Iowa, in May 2008, we have noted a small, but important change in the rhetoric about children and schooling (as a portion of the discourse related to ICE enforcement) and a misleading larger change in the practice of ICE. In the newer raid, parents, or at least mothers, apprehended in ICE raids were treated differently; they were not immediately deported or even transported away from the community where they lived (and were arrested). Rather, the new practice, rationalized as a way to avoid separating children from their mothers and leaving children without a caretaker, was to place mothers in at-home detention. In turn, at least temporarily, children of detained parents could stay in local schools. 
We think that this newer ICE practice stemmed directly from the cultural models invoked in local responses related to deportations and vulnerable children that the original Swift raids precipitated. We also note that this new strategy, if less swiftly and thoroughly traumatic, nonetheless perpetuated the actual vulnerability of the children, although their safety was cited as a reason for the policy change. The policy change reduced the dilemma of schools serving as sites of refuge. However, keeping parent and child together when parents were blocked from any kind of viable livelihood (as the mujeres de bracelates were) was hardly an improvement in that child's circumstance. In other words, the new cultural model that lamented schools needing to be sites of refuge and the continuing cultural model of children as innocent and vulnerable led to a reimagining of the appropriate "how tos" of ICE enforcement. In practice, this kinder, gentler enforcement was ultimately not much less disadvantaging to the newcomers (they still had to leave in the end after savings were depleted and months were spent in federal or housebound detention), but it was consistent with regional sensibilities of avoiding drama and trauma. Moreover, it maintained a stance that humanized the Latino newcomers. In addition to being laborers, media depictions insisted that they were mothers, Christians, and students.

Related to the Postville raid, Iowan and national media (notably the New York Times) maintained outraged stances toward allegations of employee abuse. Then the continuing presence of the home-detained women, which meant their status as mothers was a regularly invoked cultural model, enabled continued contestation of the consequences of the raids and shaped the framing of immigrants, established residents, teachers, parents, children, and detainees.

Small Flyover Country meatpacking communities were not, per mainstream media voices, acquiescent to the appropriateness and consequences of the raids. Indeed, in a region that is better known for its presumed conservatism, it is striking that the local invocation of cultural models stood apart from the ostensibly national conservative storylines that supposedly rationalize the strategy of raids, detentions, and deportations. Everyday sensibilities for keeping parents with children, for assuring that kids had parents to go home from school to, for not adding to the obligations of schools, for receiving a fair wage for hard work, and the like, tell a different story of this region and of the ways newcomers' place and membership were understood there. Mainstream media voices were not the only voices, but they were powerful ones and they reasserted claims of community cohesion, the decency of neighbor with neighbor, and the inappropriateness of children being subject to the collateral damage that are inevitable byproducts of ICE enforcement actions.

While these mainstream voices may not have stopped raids, nor made children less vulnerable, they are compelling for at least two reasons: they suggest in Flyover Country a resistance to dehumanizing and thereby pejorative characterizations (Murillo 2002) of Latino newcomers and they suggest constituent pieces, specifically, the already extant cultural models, that could be invoked in a long-term and broader effort to support Latino newcomers.

As the Council of Anthropology and Education continues to consider how to make its work relevant to both public policy and the quest for social justice (Hamann et al. 2007), more works like this are needed. Wolcott (2011:108) worries that the quest for social justice can be a distraction to the subdiscipline and emphasizes that we should be uncovering "what meaning" patterns of behavior have for those who live them. While focusing on public sphere voices does not capture the full gamut of local opinion, it does draw our attention to a consequential local voice that is often overlooked in scholarship. In so doing, at a time of heightened xenophobia and social separation, we are reminded that mainstream, establishment voices in Flyover Country might be invoked for alliances that welcome Latino newcomers. Our work at documentation can be repurposed as a tool for social justice. 
Acknowledgments - We would like to thank the editors of Anthropology \& Education Quarterly and the anonymous reviewers who have helped us improve this manuscript substantively.

\section{References Cited}

Benson, Adam

2006 Families Stunned by Sweep. Herald Journal, December 13. http:// hinews.townnews.

Black, Ken com/articles/2006/12/13/news/news02.txt ; accessed December 18, 2006. [Logan, UT]

2006 Harkin Expresses Concern Over Swift Raid. Times-Republican, December 20. http:// www.timesrepublican.com/News/articles.asp?articleID=5220; accessed December 20, 2006. [Marshalltown, IA]

Culver, Chet

2008 Guest Column: Governor-Agriprocessors Must Operate Responsibly. Des Moines Register, August 24: OP3.

Delgado, Vanessa

2006 After ICE Raid, Families Celebrating Christmas but Still Searching for Family Members. Greeley Tribune, December 17. http://www.greeleytrib.com/article/20061217/ NEWS/112160109; accessed December 20, 2006.

Duara, Nigel

2008 Mother, Two Kids Contemplate Eventual Return to Guatemala. Des Moines Register, July 16. http:/ / www.desmoinesregister.com/apps/pbcs.dll/article?AID=/20080716/ NEWS/807160372/1001; accessed July 25, 2008.

Duara, Nigel, Grant Schulte, and William Petroski

2008 ID Fraud Claims Bring State's Largest Raid. Des Moines Register, May 13: A1.

Erickson, Frederick

1987 Transformation and School Success: The Politics and Culture of Educational Achievement. Anthropology and Education Quarterly 18(4):335-356.

Geraci, Charles

2006 Police Assisting Hispanic Community. Herald Journal, December 19. [Logan, UT]

Greeley Tribune

2006 Editorial: It's Not Just About Illegal Immigrants. Greeley Tribune, December 17. http:// www.greeleytrib.com/article/20061217/TRIBEDIT/112170096; accessed December 20, 2006.

Greeley Tribune Staff Reports

2006 Greeley Detainees Being Transported Back to Colorado. Greeley Tribune, December 17. http://www.greeleytribune.com/article/20061217/NEWS/112170091\&parentprofile=sea rch ; accessed November 21, 2011.

Hamann, Edmund T.

2003a The Educational Welcome of Latinos in the New South. Westport, CT: Praeger.

2003b Reflections on the Field: Imagining the Future of the Anthropology of Education if We Take Laura Nader Seriously. Anthropology and Education Quarterly 34(4):438-449.

2011 The Anglo Politics of Latino Education: The Role of Immigration Scripts. In The Politics of Latino Education. David L. Leal and Ken J. Meier, eds. Pp. 103-121. New York: Teachers College Press.

Hamann, Edmund T., Kimberly S. Anderson, Bradley A. U. Levinson, Chiara Cannella, Mica Pollock, and Susan Wright

2007 Educational Policy as a Matter for Anthropologists' Scholarly and Applied Engagement: Report of the Council on Anthropology and Education's Ad Hoc Committee on Educational Policy. https://www.aaanet.org/sections/cae/pdf\%20files/CAE_AdHoc_Committee_Anthropological_Engagement.pdf ; accessed March 17, 2011.

Hanks, Christopher

2011 The Double-Edge of Reason: Jürgen Habermas and the Frankfurt School. In Beyond Critique: Exploring Critical Social Theories and Education. Bradley A. U. Levinson, ed. Pp. 80112. Boulder, CO: Paradigm. 
Lakoff, George, and Sam Ferguson

2006 Framing Immigration. Berkeley, CA: Rockridge Institute. http:/ / www.cognitivepolicyworks.com/resource-center/rethinking-immigration/the-framing-of-immigration/ ; ac-

Leys, Tony cessed March 17, 2011.

2008 Guatemala: Hope at Any Cost. Des Moines Register, November 30: SP1.

Murillo, Enrique G., Jr.

2002 How Does It Feel To Be a Problem? "Disciplining" the Transnational Subject in the New South. In Education in the New Latino Diaspora: Policy and the Politics of Identity. Stanton Wortham, Enrique G. Murillo, and Edmund T. Hamann, eds. Pp. 215-240. Westport, CT: Ablex.

Nader, Laura

1969 Up the Anthropologist - Perspectives Gained from "Studying Up." In Reinventing Anthropology. Dell Hymes, ed. Pp. 284-311. New York: Pantheon.

Navarette, Ruben

2008 Those against Immigration Raids Railing against Wrong Issue. Lincoln Journal-Star, July 31: 5B.

Overstreet, Tracy

2006 Union: Civil Rights Violations Occurred with Swift Raid. Grand Island Independent, December 20. http://www.swiftraid.org/media/articles/12-20-06TheIndependent.pdf ; accessed November 21, 2011.

Pore, Robert

2006 A Community's Pain: Hundreds Attend Vigil for Those Affected by Last Week's Immigration Raid. Grand Island Independent, December 18. http://www.swiftraid.org/media/ articles/12-18-06TheIndepACommPain.pdf ; accessed November 21, 2011.

Preston, Julia

2006 Immigrants' Families Figuring Out What to Do after Federal Raids. New York Times, December 16. http://www.swiftraid.org/media/articles/12-16-06NYTimesImmigrantFamilies.pdf; accessed November 21, 2011.

Quinn, Naomi, and Dorothy Holland

1987 Culture and Cognition. In Cultural Models in Language and Thought. Dorothy Holland and Naomi Quinn, eds. Pp. 3-40. Cambridge: Cambridge University Press.

Reynolds, Jennifer R., and Caitlin Didier

[In press] Contesting Diversity and Community within Iowa's "Hometown to the World." In Latin American Migrations to the U.S. Heartland: Reshaping Communities, Redrawing Boundar-

Rhor, Monica ies. A. Wood and L. Allegro, eds. Champaign: University of Illinois Press.

2008 A Small Town Struggles after Immigration Raid. Associated Press Online, August 17. http://ap.google.com/article/ALeqM5jn-owzFkBuk-MJjZ-y3cLtOZf2pwD92JV3300 ; accessed August 28, 2008.

Rockwell, Elsie

2011 Recovering History in the Anthropology of Education. In A Companion to the Anthropology of Education. Bradley A. U. Levinson and Mica Pollock, eds. Pp. 65-80. Chichester, UK:

Rosen, Lisa Wiley-Blackwell.

2009 Rhetoric and Symbolic Action in the Policy Process. In Handbook of Education Policy Research. Gary Sykes, Barbara Schneider, and David N. Plank, eds. Pp. 267-285. New York: Routledge.

Santa Ana, Otto

2002 Brown Tide Rising: Metaphors of Latinos in Contemporary American Public Discourse. Austin: University of Texas Press.

Suárez-Orozco, Marcelo M.

1998 State Terrors: Immigrants and Refugees in the Post-National Space. In Ethnic Identity and Power: Cultural Contexts of Political Action in School and Society. Yali Zou and Enrique T. Trueba, eds. Pp. 283-319. Albany: State University of New York Press. 
Trejo, Frank, and Isabel Morales

2006 Raid, Fear Tear Apart Families: Many Uncertain about Future, and Children's Plight Is Foremost Worry. Dallas Morning News, December 13. http://www.dentonrc.com/sharedcontent/dws/news/texassouthwest/stories/121406dntexcactustown.35bf149.html ; accessed December 18, 2006.

Wettschreck, Justine

2006 Union Decries Action. Worthington Daily Globe, December 14. http:/ / www.swiftraid. org/media/articles/12-14-06DailyGlobeUnionDecries.pdf ; accessed November 21, 2011.

Wheeler, Emilie H.

2006 Educators Focused on Well-Being of Children. Herald Journal, December 14. http:// news.hjnews.com/news/article e6ddc89c-5165-5080-b3e9-fb83f391328a.html ; accessed

Wolcott, Harry December 18, 2006. [Logan, UT]

1988 "Problem Finding" in Qualitative Research. In School and Society: Learning Content through Culture. Henry T. Trueba and Concha Delgado-Gaitan, eds. Pp. 11-35. New York: Praeger.

2011 "If There's Going to Be an Anthropology of Education ..." In A Companion to the Anthropology of Education. Bradley A. U. Levinson and Mica Pollock, eds. Pp. 97-111. Chichester, UK: Wiley-Blackwell.

Worthington Daily Globe

2006 What Are Your Thoughts on the U.S. Immigration and Customs Enforcement (ICE) Raid at Swift? (On-Line Open Forum). http://www.dglobe.com/talk/index.cfm?id=28\&talk page $=12$; accessed December 21, 2006. 